\title{
IDENTIFIKASI DAN PREVALENSI CACING PADA SALURAN PENCERNAAN IKAN SALEM (Scomber japonicus) DI PANGKALAN PENDARATAN IKAN MUARA ANGKE, JAKARTA UTARA
}

\section{IDENTIFICATION AND PREVALENCE OF HELMINTHIC GASTROINTESTINAL IN CHUB MACKEREL (Scomber japonicus) IN THE FISH LANDING BASE MUARA ANGKE, NORTH JAKARTA}

\author{
Rengga Eko Pradipta, Sri Subekti dan Kismiyati
}

Fakultas Perikanan dan Kelautan Universitas Airlangga

Kampus C Mulyorejo - Surabaya, 60115 Telp. 031-5911451

\begin{abstract}
The high interest of public to Marine fish, making more request of chub mackerel (Scomber japonicus). Chub Mackerel is one commodity that has economic and high nutrient value. The Chub Mackerel obtained from the Indonesian importation from China. However, fish importation can be affected by diseases caused by helminthic endoparasites infection.

The parasites that infected chub mackerel probably be caused by pollution due to environmental factors that could decreased the immune system, and making a fish easily infected by helminthic endoparasite as Anisakis. This parasite is zoonosis and could infected to human. Therefore, identification and prevalence of this parasite was needed in order to human consumed and managed this fish correctly.

The purpose of this study was to identify and to know the prevalence of this helminth that infected a chub mackerel fish (Scomber japonicus) from fish importation that were sold in Fish Landing Base Muara Angke, North Jakarta. Research methodology using survey methods through sampling at locations directly. Fish samples were examined as many as 60 samples of chub mackerel. The main parameters are observed prevalence of helminth and helminth that infect in gastrointestinal chub mackerel. The result identification of helmint that infect chub mackerel descriptively analyzed and presented in the form of figures and tables.

The result showed the presence of the third-stage larvae Anisakis simplex that infected the intestinal mucosa and lumen of chub mackerel fish, in Fish Landing Base Muara Angke, North Jakarta with prevalence was $70 \%$.
\end{abstract}

Keywords : Chub Mackerel, Prevalence, Anisakis simplex, and Zoonosis

\section{Pendahuluan}

Pangkalan Pendaratan Ikan (PPI) Muara Angke berada di Jakarta Utara dan merupakan tempat pendaratan ikan terbesar di Jakarta Utara. PPI Muara Angke memiliki peranan strategis dalam pengembangan perikanan dan kelautan, yaitu sebagai pusat atau sentral kegiatan perikanan laut serta berperan penting dalam meningkatkan Pendapatan Asli Daerah (PAD), dimana pada tahun 2012 mampu menghasilkan ikan mencapai $20.085 .570 \mathrm{~kg}$ ikan laut dengan nilai Rp. 40.018.938.730,00, dibandingkan pada tahun sebelumnya yang mencapai $18.753 .870 \mathrm{~kg}$ ikan laut dengan nilai Rp. 37.561.781.640,00 (Dinas Kelautan dan Perikanan, 2013).

Salah satu ikan yang dipasarkan di TPI Muara Angke adalah Ikan salem (Scomber japonicus). Direktorat Jenderal Pengolahan dan Pemasaran Hasil Perikanan (2012) telah menetapkan bahwa ikan salem (Scomber japonicus) merupakan ikan impor sebagai bahan baku industri pengolahan ikan tradisional berupa pemindangan di Indonesia dan dipasarkan di TPI dalam keadaan beku. Menurut data Direktorat Jenderal Perikanan (2013), impor ikan salem pada tahun 2012 mencapai 120.436 ton, mengalami peningkatan dimana pada tahun 2011 mencapai 93.781 ton. Menurut (Hernandez and Ortega, 2000). ikan salem merupakan ikan yang hidup bebas di alam pada perairan epipelagik hingga mesopelagik (biasanya 50-300 m) dan hidup bergerombol dengan sesama jenis dan ukurannya. Pada malam hari, secara bergerombol ikan salem naik ke permukaan laut untuk memangsa euphausids, copepods, amphipods, anchovies, dan cumi-cumi kecil sehingga ikan salem termasuk golongan ikan karnivora.

Ikan sama seperti makhluk hidup lainnya, tidak pernah lepas dari ancaman 
berbagai penyakit dan salah satunya penyebab penyakit tersebut adalah parasit. Parasit merupakan organisme yang hidup pada atau di dalam organisme lain, mengambil makanan dari organisme yang ditumpanginya untuk berkembang biak (Subekti dan Mahasri, 2010). Berdasarkan habitatnya, parasit dalam tubuh ikan dibagi menjadi dua yaitu ektoparasit (parasit yang menyerang bagian permukaan tubuh ikan atau pada rongga yang berhubungan langsung ke permukaan tubuh ikan, misalnya pada insang, sirip dan kulit), dan endoparasit (parasit yang menginfeksi organ bagian dalam tubuh ikan, misalnya usus, ginjal dan hati) (Olsen, 1974). Infeksi parasit dapat menyebabkan kerugian pada inang definitif misalnya menghambat pertumbuhan dan penurunan produksi. Infeksi cacing pada manusia dapat berdampak terhadap kesehatan manusia (zoonosis) yang ditandai dengan gejala sakit pada abdomen, kejang dan muntah (Palm, 2008). Oleh karenanya diperlukan pemahaman terhadap cacing parasitik dan penyakit yang ditimbulkannya terutama yang berasal dari ikan untuk dapat mengembangkan berbagai produk asal ikan terutama untuk konsumsi manusia (Yamaguti 1958 dalam Emelina 2008).

Dengan demikian berdasarkan hal-hal yang telah dikemukakan dan juga karena sedikitnya informasi mengenai jenis parasit apa saja yang menyerang ikan salem (Scomber japonicus), maka perlu dilakukan penelitian tentang identifikasi dan prevalensi cacing pada saluran pencernaan ikan salem (Scomber japonicus) di Pangkalan Pendaratan Ikan Muara Angke, Jakarta Utara

\section{Materi dan Metode}

Tempat dan Waktu

Penelitian ini dilaksanakan di

Laboratorium Pendidikan Fakultas Perikanan dan Kelautan Universitas Airlangga dan Balai Karantina Ikan Tanjung Priok pada bulan Maret-April 2014. Pengambilan sampel dilakukan di Pangkalan Pendaratan Ikan Muara Angke, Jakarta Utara.

\section{Alat dan Bahan}

Peralatan yang akan digunakan dalam pemeriksaan parasit adalah gunting, pinset, pisau bedah dan nampan. Alat yang digunakan untuk identifikasi parasit adalah gelas objek, cover glass, dan mikroskop.

Bahan yang diperlukan untuk proses identifikasi endoparasit adalah ikan sampel, tisu dan aquades sedangkan bahan yang digunakan untuk pewarnaan parasit yang ditemukan adalah larutan alkohol gliserin 5\%, zat pewarna carmine, alkohol asam, alkohol basa, alkohol $70 \%$, alkohol $85 \%$, alkohol $95 \%$, Hungs I dan Hungs II.

Pengambilan Sampel

Metode pengambilan sampel dilakukan yaitu dengan mengambil ikan dari Pangkalan Pendaratan Ikan Muara Angke. Perhitungan masing-masing jumlah sampel ikan yang diambil sebesar 5-10\% dari jumlah total populasi ikan (Balai Karantina Ikan Batam, 2007). Jumlah populasi rata-rata impor ikan salem di PPI Muara Angke sebanyak 450 ekor per hari. Pengambilan sampel dilakukan secara acak (random sampling) sebanyak tiga kali. Masing-masing pengambilan ikan sebanyak 20 ekor ikan salem.

\section{Pemeriksaan Parasit}

Sampel diambil dan diletakkan di atas nampan, kemudian dilakukan pembedahan dengan gunting mengarah ke anterior tubuh sampai pada bagian sirip ventral, kemudian digunting ke arah dorsal ikan sampai pada bagian gurat sisi lalu digunting mengarah pada bagian anal ikan. Lambung ikan bagian anterior dipotong sampai pada bagian posterior usus, kemudian diperiksa di atas cawan petri dan diinsisi untuk diperiksa keberadaan cacing pada organ tersebut. Cacing yang ditemukan disimpan di dalam larutan alkohol glycerin $5 \%$. (Aryani, 2012).

\section{Pewarnaan Ektoparasit}

Pewarnaan cacing yang ditemukan pada saluran pencernaan ikan salem (Scomber japonicus) dilakukan berdasarkan Kuhlman (2006) dengan cara cacing disimpan dalam alkohol gliserin 5\% selama 24 jam. Kemudian dimasukkan dalam alkohol $70 \%$ selama lima menit. Setelah itu, memindahkan cacing dalam larutan carmine selama empat jam, kemudian cacing dipindahkan dalam larutan alkohol asam selama dua menit. Setelah selesai, dipindahkan dalam larutan alkohol basa selama 20 menit. Selanjutnya dilakukan dehidrasi bertingkat dengan alkohol 70\%, 85\%, dan 95\% masingmasing selama lima menit. Kemudian dilakukan mounting dengan menggunakan Hungs I, cacing diambil lalu diletakkan di object glass, dan ditetesi larutan Hungs II, kemudian ditutup dengan cover glass.

\section{Perhitungan Prevalensi}

Prevalensi adalah besarnya persentase ikan yang terinfestasi dari ikan contoh yang diperiksa. Menurut Mohammed (2007) 
prevalensi dihitung menggunakan rumus sebagai berikut:

Prevalensi $=$

$\frac{\text { Jumlah ikan yang terserang }}{\text { Jumlah sampel ikan yang diperiksa }} \times 100 \%$

Hasil identifikasi cacing dari 60 sampel ikan yang telah diperiksa pada saluran pencernaan ikan salem (scomber japonicus) di Pangkalan Pendaratan Ikan Muara Angke Jakarta Utara hanya ditemukan satu jenis species yaitu larva stadium tiga Anisakis simplex. Cacing dari Ordo Ascaridida tersebut ditemukan menempel di permukaan dinding perut, lambung, otot, dan usus (mukosa dan lumen).

Cacing yang ditemukan menurut kunci identifikasi adalah larva stadium tiga Anisakis simplex, cacing tersebut merupakan Phylum dari Nemathelmintes, Kelas Nematoda, Ordo Ascaridida, Famili Anisakidae, Genus Anisakis (Grabda, 1991). Larva stadium tiga A. simplex yang ditemukan memiliki warna putih susu, berukuran panjang 10-29 mm dengan diameter 0,4-0,9 mm, ditemukan dalam bentuk lurus dan melingkar (coil) yang dibungkus oleh kista halus. Larva stadium tiga Anisakis simplex yang ditemukan memliki bentuk tubuh silindris memanjang, di bagian anterior (Gambar 1) cacing tersebut memiliki bibir (larval tooth) yang mengelilingi mulut, organ tersebut digunakan untuk mengambil makanan dari inang. Sedangkan di bagian posterior terdapat mukron dan saluran ekskresi (Gambar 2). Selain itu larva ketiga $A$. simplex juga memiliki esophagus yang lurus berbentuk silindris, dan dilanjutkan dengan adanya ventrikulus berupa otot yang menghubungkan langsung pada usus. Ventrikulus yang terletak di antara esophagus dan usus menjadi ciri khas A. simplex dari jenis nematoda lainnya.
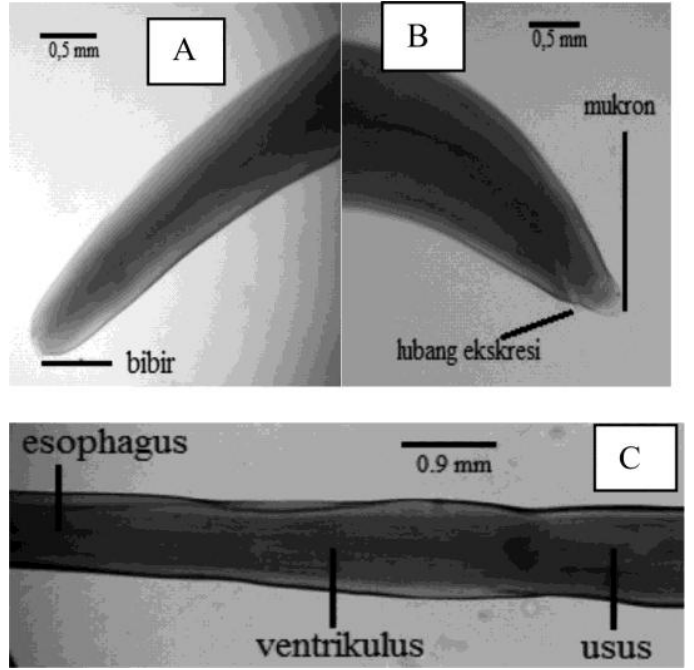

Gambar 1. Larva stadium tiga Anisakis simplex pada ikan salem (mikroskop binokuler)

Keterangan: A. Bagian anterior A. simplex (perbesaran 100x)

B. Bagian posterior A. simplex (perbesaran 100x)

C. Bagian ventriculus $A$. simplex (perbesaran 40x)

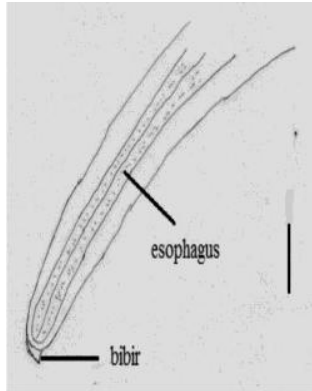

(A)

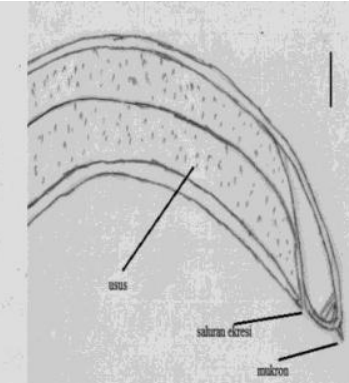

(B)

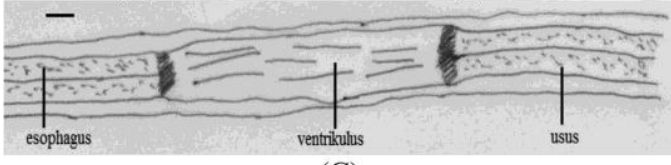

(C)

Gambar 2. Larva tiga Anisakis simplex pada ikan salem (Camera Lucida)

Keterangan : (a) bagian anterior A. simplex. (b) bagian posterior A. simplex. (c) bagian ventriculus $A$. simplex. Skala bar $=0,5 \mathrm{~mm}(\mathrm{a}-\mathrm{b})$ dan $0,8 \mathrm{~mm}(\mathrm{c})$.

Prevalensi Larva Cacing Anisakis simplex

Hasil penelitian menunjukkan bahwa tingkat prevalensi cacing pada setiap ukuran panjang ikan bervariasi. Data perhitungan prevalensi cacing pada ikan salem berdasarkan panjang ikan dapat dilihat pada Tabel 1. 
Tabel 1. Prevalensi dan Intensitas Infeksi Larva Stadium Tiga Anisakis simplex Berdasarkan Perbedaan Ukuran Panjang Ikan Salem

\begin{tabular}{cccc}
\hline $\begin{array}{c}\text { Panjang ikan } \\
(\mathrm{cm}) / \text { fase }\end{array}$ & $\begin{array}{c}\text { Jumlah } \\
\text { Ikan }\end{array}$ & $\begin{array}{c}\text { Ikan yang Prevalensi } \\
\text { terinfeksi }\end{array}$ & $(\%)$ \\
\hline $\begin{array}{c}18-28 \\
\text { (muda) }\end{array}$ & 51 & 34 & 66,67 \\
$29-30$ & 9 & 9 & 100 \\
(dewasa) & & & \\
\hline Jumlah & 60 & 42 & 70 \\
\hline
\end{tabular}

Tabel 1. menjelaskan dari hasil penelitian terhadap 60 ekor ikan salem (Scomber japonicus) yang didapatkan di Pangkalan Pendaratan Ikan Muara Angke ditemukan hasil 42 ekor ikan yang terinfeksi larva ketiga Anisakis simplex dengan prevalensi 70 . Berdasarkan perbedaan ukuran ikan terdapat 51 ekor ikan salem dengan ukuran $18-28 \mathrm{~cm}, 34$ ekor diantaranya terinfeksi larva ketiga $A$. simplex dengan prevalensi 66,67\%, dan 9 ekor berukuran $29-30 \mathrm{~cm}$, semua ikan terinfeksi sehingga prevalensinya $100 \%$. Panjang ikan dibedakan sesuai dengan kategori fase ukuran ikan salem (Scomber japonicus) yang telah ditentukan oleh Hernandez and Ortega (2000) yang menyebutkan ikan muda mempunyai ukuran $15-28 \mathrm{~cm}$ dan ikan dewasa mempunyai ukuran lebih dari $28 \mathrm{~cm}$.

\section{Hasil dan Pembahasan}

Hasil penelitian menunjukkan bahwa ditemukan larva stadium tiga Anisakis simplex yang berwarna putih susu dan telah memiliki larval tooth dan mukron. A. simplex yang ditemukan memiliki saluran ekskresi di bagian posterior dan memiliki esophagus, ventrikulus dan usus yang terlihat jelas. Sugane et al. (1992) menerangkan bahwa karakteristik Anisakis simplex mempunyai larval tooth yang menonjol di ujung anterior. A. simplex biasa ditemukan melingkar dan berwarna putih atau cream dengan struktur usus anterior lurus yang terdiri dari esophagus, ventriculus, dan usus.

Infeksi cacing Anisakis simplex pada ikan salem (Scomber japonicus) disebabkan akibat ikan salem yang memakan euphausids yang telah terinfeksi oleh larva stadium tiga Anisakis simplex. Crone et al. (2009) menyatakan bahwa ikan salem (Scomber japonicus) merupakan ikan karnivora yang memakan organisme kecil di sekitar habitatnya antara lain euphausids, copepods, amphipods, anchovies, dan cumi-cumi kecil sehingga parasit lebih banyak yang menginfeksi dibanding ikan pemakan plankton (herbivora). Rucket et al.,
(2009) menjelaskan bahwa keberadaan cacing endoparasit di dalam tubuh ikan juga bisa disebabkan karena adanya organisme invertebrata seperti crustacea di sekitar habitat dari ikan salem, yang juga merupakan salah satu jenis pakan alami dari ikan salem.

Crustacea dan ikan kecil merupakan inang antara bagi $A$. simplex, sedangkan ikan salem merupakan inang paratenik, sehingga $A$. simplex yang ditemukan masih dalam tahap larva stadium tiga. Klimpel et al., (2004) menerangkan bahwa Anisakis simplex membutuhkan crustacea kecil (euphausiids) dan larva ikan kecil sebagai inang antaranya. Sebelum mencapai tahap cacing dewasa ketika menginfeksi inang definitifnya yaitu mamalia laut, Anisakis simplex masih berupa larva stadium tiga di inang paratekniknya (piscivores / herring).

Infeksi cacing larva tiga A. simplex pada ikan tidak menunjukkan gejala klinis yang khas, sebab ikan sampel yang diamati tidak mengalami perubahan pada bagian eksternalnya. Hal tersebut sesuai dengan pernyataan Sarjito dan Desrina (2005) yang menyatakan bahwa infeksi endoparasit tidak menunjukkan gejala klinis eksternal dan sulit untuk terdeteksi dengan cepat, sehingga perlu dilakukan pembedahan dan pengamatan organ dalamnya.

Distribusi infeksi larva cacing Anisakis simplex pada ikan salem (Scomber japonicus) di Pangkalan Pendaratan Ikan Muara Angke terdapat pada dinding perut, lambung, usus, dan otot sedangkan pada organ lainnya tidak ditemukan larva cacing A. simplex. Menurut Williams and Jones (1994) mikrohabitat parasit adalah lingkungan/tempat yang mendukung kehidupan parasit. Lingkungan / tempat tinggal tersebut harus tersedia makanan, oksigen dan faktor lainnya termasuk di dalamnya kompetisi antar spesies. Menurut Rakibuzzaman (2011) persebaran Anisakis simplex pada beberapa organ yaitu untuk melengkapi siklus hidupnya. Terdapatnya Anisakis simplex pada rongga tubuh dan saluran pencernaan karena banyaknya sumber bahan organik yang siap serap oleh cacing tersebut, sebagaimana diketahui makanan dari parasit nematoda adalah sel jaringan dan cairan tubuh.

Tingkat prevalensi larva stadium tiga A. simplex pada ikan salem (Scomber japonicus) di pangkalan pendaratan ikan Muara Angke sebesar 70\%. Menurut kategori infeksi berdasarkan Williams and Williams (1996), prevalensi ikan salem yang telah diteliti termasuk kategori Usually (89-70\%), masih tergolong satu kategori dari penelitian yang 
dilakukan oleh Cisse and Belghyti (2005) dengan prevalensi $86,67 \%$.

Hasil penelitian terhadap ikan salem (Scomber japonicus) memperlihatkan adanya hubungan antara ukuran panjang ikan dengan prevalensi dan intensitas infeksi Anisakis simplex. Berdasarkan perbedaan ukuran ikan terdapat 51 ekor ikan salem dengan ukuran 18 $28 \mathrm{~cm}, 34$ ekor diantaranya terinfeksi larva ketiga A. simplex dengan prevalensi $66,67 \%$, dan 9 ekor berukuran $29-30 \mathrm{~cm}$, semua ikan terinfeksi sehingga prevalensinya $100 \%$. Dari hasil tersebut dapat disimpulkan bahwa ada hubungan perbedaan ukuran ikan dengan prevalensi dimana menurut kategori infeksi, ukuran ikan $18-28$ termasuk kategori frequently, sedangkan ukuran ikan 29 - 30 termasuk kategori yang paling tinggi yaitu always. Prevalensi dan intensitas ini dipengaruhi oleh ukuran ikan salem (Scomber japonicus), semakin besar ukuran ikan maka semakin besar kesempatan ikan terpapar oleh $A$. simplex. Hal ini dikuatkan oleh pendapat Hariyadi (2006) yang menyebutkan infeksi larva Anisakis simplex meningkat dengan makin bertambahnya ukuran ikan. Semakin panjang ukuran ikan berarti umur ikan semakin bertambah, sehingga kesempatan terpapar oleh larva cacing Anisakis simplex juga semakin banyak. Komentar tersebut didukung oleh Mahmoud and Mahmoud (2005) yang mengungkapkan bahwa tubuh ikan adalah tempat untuk kolonisasi parasit. Semakin luas permukaan tubuh ikan, maka koloni parasit juga bertambah, sehingga nilai prevalensi dan intensitas parasit meningkat. Selain faktor tersebut, umur ikan juga mempengaruhi prevalensi dan intensitas sebagaimana dijelaskan oleh Kennedy (1975) bahwa semakin tua ikan, berarti semakin lama waktu yang dimiliki ikan untuk kontak dengan parasit, sehingga prevalensi dan intensitas parasit meningkat sesuai dengan umur ikan.

Cacing parasit pada ikan salem yang telah diteliti tidak terdapat keragaman. Hal ini dimungkinkan karena ikan salem hidup di satu tipe perairan saja. Menurut Mahmoud and Mahmoud (2005) ikan yang menghabiskan seluruh siklus hidupnya hanya di satu tipe perairan akan memilki parasit lebih sedikit daripada ikan yang berpindah-pindah, sebaliknya ikan yang hidup di dua perairan yang berbeda cenderung memiliki parasit lebih beragam. Ikan salem, meskipun nilai prevalensi parasitnya cenderung naik tetapi keragaman spesies parasitnya rendah.

Nilai prevalensi pada ikan salem yang tergolong tinggi ini dapat berpotensi zoonosis.
Anisakis simplex dapat menginfeksi manusia melalui mekanisme memakan ikan Scomber japonicus yang kurang masak. Dalam tubuh manusia larva akan hidup dan umumnya tetap sebagai larva stadium ketiga, larva tersebut menembus jaringan mukosa usus, kasus infeksi umumnya tidak menunjukkan gejala tetapi larvanya terkadang bisa ditemukan ketika larva hidup keluar melalui muntah atau feses (Sugane et al., 1992). Anisakis simplex pada manusia dapat menyebabkan beberapa gejala antara lain rasa sakit pada perut bagian bawah, mual, muntah, demam, diare, dan adanya darah dalam feses. Untuk mencegahnya agar tidak mengkonsumsi ikan yang kurang matang, sebaiknya memakan ikan yang matang seperti hasil penggorengan karena minyak goreng memiliki titik didih $200^{\circ} \mathrm{C}$ (Miyazaki, 1991). Kasus Anisakiasis sering dijumpai di negara Jepang, pada tahun 2011 Jepang menyumbang 90\% dari semua kasus Anisakiasis, hal ini disebabkan karena mayoritas masakan tradisional Jepang menggunakan ikan yang kurang matang (sushi dan sashimi). Di negara lain misalnya Italia, zoonosis Anisakis simplex juga ditemui di beberapa daerah pesisir, yang sebagian besar disebabkan oleh konsumsi ikan laut yang mentah atau makanan berupa sushi, sashimi, dll (Bucci et al., 2013).

\section{Kesimpulan}

Berdasarkan hasil penelitian dapat disimpulkan bahwa cacing yang ditemukan pada saluran pencernaan ikan salem (Scomber japonicus) yang diambil di Pangkalan Pendarata Ikan Muara Angke, Jakarta Utara adalah larva stadium tiga Anisakis simplex. Prevalensi ikan salem (Scomber japonicus) yang diambil sebanyak 60 ekor dari Pangkalan Pendaratan Ikan Muara Angke, Jakarta Utara yang terinfeksi oleh cacing larva stadium tiga Anisakis simplex sebesar 70\% (Usually).

Dengan ditemukannya cacing Anisakis simplex pada saluran pencernaan ikan salem (Scomber japonicus), maka diperlukan pengolahan yang baik dan benar sebelum ikan tersebut dikonsumsi, karena bersifat zoonosis.

\section{Daftar Pustaka}

Aryani, R. 2012. Identifikasi dan Prevalensi Cacing pada Saluran Pencernaan Ikan Gurami (Osphronemus gouramy) di Desa Ngrajek Magelang Jawa Tengah. Skripsi. Budidaya Perairan. Fakultas Perikanan dan Kelautan. Universitas Airlangga. Surabaya. 43 hal.

Balai Karantina Ikan Batam. 2007. Laporan Pemantauan HPI/HPIK Tahun 2007. 
Balai Karantina Ikan Batam. Batam. 52 hal.

Bucci, C., G. Serena., M. Ivonne., Fortunato., C. Carolina., I. Paola. 2013. Anisakis, just think about it in an emergency!. Int. J. Infect. Dis. 17(11): 1071-1072.

Cisse, M., and D. Belghyti (2005). Helminth Parasites of Chub Mackerel Scomber japonicus (Houttuyn, 1782) from Mehdia-Kenitra Harbour (Atlantic Coast of Morocco). J.Aqu. Sci., 20 (1): 63-67.

Crone, P. R., K. T. Hill, J. D. McDaniel, and N. C. H. Lo. 2009. Pacific Mackerel (Scomber japonicus) Stock Assessment for USA Management in the 2009-10 Fishing Year. Pacific Fishery Management Council. Ambassador Place. USA. 197 p.

Dinas Kelautan dan Perikanan. 2013. Laporan Hasil Tangkapan Beberapa Ikan di Jakarta Utara. Departemen Perikanan. 34 hal.

Direktorat Jenderal Pengolahan dan Pemasaran Hasil Perikanan. 2012. Penetapan Jenis-Jenis Hasil Perikanan yang dapat Dimasukkan ke Dalam Wilayah Negara Republik Indonesia. Departemen Perikanan. 15 hal.

Direktorat Jenderal Perikanan. 2013. Statistik Perikanan Indonesia 2012. Departemen Pertanian. Jakarta. 75 hal.

Emelina, N. 2008. Cacing Parasitik pada Insang Ikan Kembung (Decapterus spp). Skripsi. Fakultas Kedokteran Hewan. Institut Pertanian Bogor. Bogor. 56 hal.Pertanian Bogor. Hal 42.

Grabda, J. 1991. Marine Fish Parasitology. VHC and PWN-Polish Scientific Publishers, New York. hal. 5-27.

Hariyadi, A.R. (2006). Pemetaan Infestasi Cacing Parasitik dan Resiko Zoonosis pada Ikan Laut di Perairan laut Indonesia Bagian Selatan. Tesis. Bogor: Fakultas Kedokteran Hewan. Institut

Hernandez, C. J. J. and A.T. S Ortega, 2000. Synopsis of Biological Data on The Chub Mackerel (Scomber japonicus Houttuyn, 1782). FAO Fish. Synop. 157. $77 \mathrm{p}$

Kennedy, C. R. 1975. Ecological Animal Parasitology. Blackwell Scientific Publications. Oxford London. pp. 53-61.

Klimpel, S., H. W. Palm, S. Ruckert and U. Piatkowski. 2004. The Life Cycle of Anisakis simplex in The Norwegian Deep (Nothern North Sea). Parasitol Res. 94: 1-9.
Kuhlmann, W.F. 2006. Preservation, Staining, and Mounting Parasite Speciment. 8 hal.

Mahmoud, N.E., and A.M. Mahmoud, (2005). Parasitological and Histopathological Studies on Anisakis simplex Larvae Infection Among Some Egyptian Marine Fishes and Experimental Anisakiasis in Mice. Egy. Vet. Med. Sci. Parasit. J., 2 (1): 213-231.

Miyazaki, I. 1991. An Illustrated Book of Helminthic Zoonosis. Tokyo International Medical Foundation of Japan. Japan. 56 p.

Mohammed, A. A. 2007. Parasites of Some Imported Fish. Thesis. Veterinary Medical Sciences. Zagazig University. Egypt. 110 p.

Olsen, O. W. 1974. Animal Parasites, Their Life Cycles and Ecology. Park Press Baltimore University. 562 p.

Palm, H.W. 2008. Molecular Genotyping of Anisakis. Journal of Science nad Technology. Vol. 3. 8 pp.

Rakibuzzaman, M. 2011. Comparative Study of Endoparasitic Infestation in Scomber Colias Collected from Sewage Lagoon. Journal of Science and Technology. 6 (2) : 6-7.

Rucket, S., S. Klimpel, S. Al-Quraishy, H. Mehlhron, and H.W. Palm. 2009. Transmission of Fish Parasites into Grouper Mariculture (Serranidae: Epinephelus coioides (Hamilton, 1882)) in Lampung Bay, Indonesia. Parasitol 104: 523-532.

Sarjito dan Desrina. 2005. Analisa Infeksi Cacing Endoparasit pada Ikan Kakap Putih (Lates calcarifer Bloch) dari Perairan Pantai Demak. Laporan Kegiatan Hasil Penelitian Dosen Muda. Fakultas Perikanan dan Ilmu Kelautan. Universitas Diponegoro. Semarang. 18 hal.

Sugane, K., S.H. Sun, and T. Matsuura, (1992). Radiolabelling of The ExcretorySecretory and Somatic Antigens of Anisakis simplex Larvae. J. Helminth., 66 (4): 305-309.

Williams, H., and A. Jones. 1994. Parasitic Worm of Fish. Taylor and Francis Ltd., London, United Kingdom.

Williams, E.H., and L.B. Williams. 1996. Parasites of Offshore Big Game Fishes if Puerto Rico an The Western Atlantic. Departement of Marine Sciences and Departement of Biology University of Puerto Rico : Puerto Rico 320p. 